\title{
SUBJECTIVITY UNDER CONSUMERISM: THE TOTALIZATION OF THE SUBJECT AS A COMMODITY
}

\author{
SUBJETIVIDAD EN EL CONSUMISMO: LA TOTALIZACIÓN DEL SUJETO \\ COMO MERCANCÍA \\ A SUBJETIVIDADE NO CONSUMISMO: A TOTALIZAÇÃO DO SUJEITO \\ COMO MERCADORIA
}

http://dx.doi.org/10.1590/1807-03102016v28n2p207

Marlon Xavier

Universitat Autónoma de Barcelona, Barcelona, España

\begin{abstract}
This theoretical work discusses consumerism's processes of subjectivation and their psychological consequences. Its regime is studied through its social imaginary and its totalitarian character: the discourse of advertising, as a global hegemon, absorbs all forms of discourse and signification, thereby actualizing capitalism's telos the colonization of the Lebenswelt under a great imperative: everything must become a commodity, especially the subject. A process of totalization of subjectivity occurs under a commodification logic centered on the representation: every image must be transformed into commodity-signs. Thus the consumption imaginary appears as a totalizing ideology, functioning as archaic représentations collectives (Durkheim) and simulating a religious imaginary. It mass-produces subjectivity through participation mystique (Lévy-Bruhl) with its commodity-signs (and their fetish) and the whole imaginary. Its subject is defined as a bricolage of consumable commodity-signs, being therefore eternally fluid, performative, and ethereal. Thus it produces an anthropological mutation, the commodity-subject: a disposable, empty, thoroughly commodified self.
\end{abstract}

Keywords: subjectivity, consumption, consumerism, social imaginary, commodification.

\section{RESUMEN}

Este trabajo teórico discute los procesos de subjetivación del consumismo y sus consecuencias psicológicas. Su régimen es estudiado a través de su imaginario social y su carácter totalitario: el discurso hegemónico de la publicidad absorbe todas las formas de discurso y significación, así realizando el telos del capitalismo - la colonización del Lebenswelt bajo un imperativo: todo debe convertirse en mercancía, en especial el sujeto. Un proceso de totalización ocurre bajo una lógica de mercantilización centrada en la representación: toda imagen debe ser transformada en signo-mercancía. El imaginario de consumo aparece como una ideología totalizante, funcionando como représentations collectives (Durkheim) arcaicas y simulando un imaginario religioso, produciendo subjetividad en masa por medio de participation mystique (Lévy-Bruhl) con sus signos-mercancía (fetiche) y con el propio imaginario. Su sujeto es definido como un bricolaje de signos-mercancía consumibles, siendo por tanto eternamente fluido, performativo y etéreo. Produce de esta manera una mutación antropológica, el sujeto-mercancía: un self desechable, vacío y totalmente mercantilizado.

Palabras-clave: subjetividad, consumo, consumismo, imaginario social, mercantilización.

\section{RESUMO}

Este trabalho teórico discute os processos de subjetivação do consumismo e suas consequências psicológicas. Seu regime é estudado através de seu imaginário social e seu caráter totalitário: o discurso hegemônico da publicidade absorve todas as formas de discurso e significação, assim realizando o telos do capitalismo - a colonização do Lebenswelt sob um imperativo: tudo deve tornar-se mercadoria, especialmente o sujeito. Um processo de totalização ocorre sob uma lógica de mercantilização centrada na representação: toda imagem deve ser transformada em signo-mercadoria. O imaginário de consumo aparece como uma ideologia totalizante, funcionando como représentations collectives (Durkheim) arcaicas e simulando um imaginário religioso, produzindo subjetividade em massa por meio de participation mystique (Lévy-Bruhl) com seus signosmercadoria (fetiche) e com o próprio imaginário. Seu sujeito é definido como uma bricolagem de signosmercadoria consumíveis, sendo portanto eternamente fluído, performativo e etéreo. Produz assim uma mutação antropológica, o sujeito-mercadoria: um self descartável, vazio e totalmente mercantilizado.

Palavras-chave: subjetividade, consumo, consumismo, imaginário social, mercantilização. 
In a society of consumers, turning into a desirable and desired commodity is the stuff of which dreams, and fairy tales, are made. Zygmunt Bauman

We are surrounded by emptiness but it is an emptiness filled with signs.

Henri Lefebvre

I shop therefore I am. April Benson

\section{Introduction}

This theoretical work proposes a broad characterization of contemporary processes of subjectivation, exploring some of their psychological consequences for the subject and focusing on the social context of consumer society and its regime of consumerism. Such proposal is derived from my doctoral thesis in Social Psychology and employs an innovative, critical theoretical approach based upon a dialogue between authors from both the sociological tradition (Durkheim, Lévy-Bruhl) and modern sociology (Baudrillard, Bauman), and Analytical (Jungian) Psychology. It also advances some psychological consequences and dynamics of such processes and offers certain hypotheses for future research.

\section{Consumer society, the regime of consumerism, and subjectivity}

Our reflections may be introduced by a basic question: why prioritize the themes of consumption and consumerism when analyzing the production of subjectivity and its sociocultural context? The answers are complex and define the politico-theoretical stance adopted in this work. Consumerism is seen as the fundamental doctrine of contemporary capitalism: a cultural ideology founded on the idea and imperative of consumption - in its common significance, but also and crucially in the sense of "using up entirely, disposing of, wasting, destroying": consumere (see Featherstone, 2007, p. 21). As such, consumerism defines accurately the profound sociocultural changes effected by capitalism today. Indeed, rather than being merely an aspect of our lives or milieu, consumption has arguably become the main definer of our culture and ethos, the chief basis of the social order; accordingly, we all become creatures defined by the "age of consumption" (Baudrillard, 1970/1998, p. 191). As a socioeconomic system, consumerism seeks to produce and shape its subjects according to its logic and needs. If industrialism was rooted in production (and its subject was thus defined by work or ownership of means of production), such emphasis has been displaced and shifted towards consumption and disposal, and, presently and most importantly, towards the production of consumers. The result is that, in our global culture, being a consumer is what ultimately defines the subject (Baudrillard, 1970/1998; Bauman, 2007; Dufour, 2008).

In that sense, consumerism represents the actualization of capitalism's tendency to total colonization, including the colonization of subjectivity. Marx (1858/1978) pointed that a totalizing imperative is characteristic of capitalism: the "development to its totality consists precisely in subordinating all elements of society to itself" (p. 278). For Lukács (1923/1971) and Castoriadis (1997), capitalism's orientation toward progressive conquest of the whole of society, effected through its logic of reification and commodification, is one of its most conspicuous specificities. Contemporarily, the actualization of such orientation appears as the relentless colonization of social and psychological forces, of life realms, or reality itself, by the capitalist ethos, and the totalizing (or even totalitarian) aspects of capitalism have been pointed out by many scholars (e.g., Guattari \& Rolnik, 1996; Leys, 2007; Liodakis, 2010).

Although such processes of colonization by capital occur in multiple and complex forms, under consumerism its colonizing force might be summarized under one principle or common denominator: commodification. For Jameson (1991), this total process of expansion through "sheer commodification" ( $\mathrm{p} . \mathrm{x}$ ) is exactly what characterizes "late or multinational or consumer capitalism" (p. 36). This new colonial order strives to establish and impose the commodity as the only referent: the imperative is that everything must become a commodity, be represented, signified, and function as a commodity, and hence follow commodity-logic and market logic. Such imperative is perhaps what best defines consumerism: "a culture of commodification” (Giroux \& Pollock, 2011).

Therefore, the theoretical and political perspective on contemporary consumer capitalism (and its imaginary) that informs this work is that its telos or goal is one of total colonization through total commodification: it represents a totalizing system/ ideology. Such perspective can be summarized through the concept of total capitalism (Dufour, 2008; Leys, 2007). Dufour underlines an aspect of this "last stage of capitalism" that is central for this work: a transformation of minds by the ideologies of neoliberalism and consumerism through education, 
mass media, and culture. Such transformation means a psychological colonization of subjectivity, which represents an anthropological mutation (Dufour, 2008). Under consumerism, commodification is not restricted to labor power, as in capitalism; it aims at the total commodification of the whole being. According to Bauman (2007, p. 12), that has become "The most prominent feature of the society of consumers ... the transformation of consumers into commodities" - the mass production of commodity-subjects.

\section{Some characteristics of consumerism and its relations with postmodernity}

The sociocultural context of consumerism also has to be analyzed in its close relation with postmodernism, which can be viewed as the cultural logic of consumer capitalism (Jameson, 1991), and with what has been called the postmodern self or subject, which reflects postmodern features. Thus both consumer society and postmodernity have been characterized as a culture of excess and superficiality (Baudrillard, 1970/1998; Bauman, 2007) in which everything tends to become transient and impermanent - which Bauman called the liquid state of modernity. It is a culture of individualism, in which the pursuit of individual happiness - in the moment, ephemeral, and obtained through the consumption, accumulation and disposal of signs of happiness - becomes "the absolute reference of the consumer society" (Baudrillard, $1970 / 1998$, p. 49). As such, this pursuit is also marked by disposability, including the "disposability of social relations, the search for pleasure that is never satiated" (Baptista, 2013, p. 56), and hedonism; an eternal search for new sensations and identities made possible by individual freedom, which according to Bauman (1997) is "the value by which all other values came to be evaluated" (pp. 2-3).

However, a distinct feature of consumerism is perhaps more central to this work: the importance that the irrational and the imaginary have for its regime. Consumption is essentially based on irrational and imaginary forces and elements, such as desires, emotions, affects, and impulses. Bauman (2007), for instance, ascribes to such elements a central import: "'consumerism' is a type of social arrangement that results from recycling mundane, permanent and so to speak 'regime-neutral' human wants, desires and longings into the principal propelling and operating force of society" (p. 28). Such "wants and desires" are of an irrational nature; to paraphrase Bell (1976), the axial principle for consumption is functional irrationality. Bauman (2007) concludes that ultimately consumerism relies "on the irrationality of consumers, not on their thoroughly informed and sober calculations; on arousing consumerist emotions, not on cultivating reason" (p. 48).

Consumption can also be seen as imaginary, which is meant in a double sense: it is based on imagination and imaginary things, and its functioning depends on images. The first sense refers to the notion that consumerism is founded on the consumption of the object not for its materiality or use-value, nor for what it is or does in any concrete sense, but for what it signifies - and it signifies through an image or representation: what is consumed is the commodityimage. That is connected to the crucial role that image plays in both postmodernity and mass consumer society (Baudrillard, 1970/1998), which Jameson (1991) called the "image society", the age of "media capitalism" (p. xviii); their dynamis consists essentially in the endless production, proliferation, and consumption of a liquid surfeit of images and signs (Featherstone, 2007). Such signs and images, as commodities, are endowed with socially perceived meanings, values, differences and markers of distinction: the irrational, immaterial, artificial fetish manufactured and attached to the commodity is what is most desired and dreamed about. Hence what is consumed is essentially the promise that the commodity and/or the act of consuming will fulfill a dream - for instance, that by consuming a certain product advertised by a celebrity, the consumer will be endowed with their characteristics, or partake of their lifestyle. I have called this dream "consumption dream", sonho de consumo, which, as a concept, can be briefly defined as: (a) Culturally, it is the matter of advertisements: elaborations of sign-value - social signification artificially attached to some form of consumption or commodity - as fetishized narratives and imagery that articulate cultural fantasies and desires, and determine the commodity-forms that promise to satisfy them; (b) Subjectively, it stands for the fantasies of consumers: the desires, fantasies, daydreams, and ideals about goods and experiences - and, in fact, life in general - that have consumption as their underlying idea or motif. They are mainly derived from - indeed, fabricated by - the advertising industry, or, as a formula, generally $(b)=(a)$. Such promise - which is never fulfilled - clearly reveals another fundamental irrational factor for consumption: "consumption is governed by a form of magical thinking ... a primitive mentality ... based on a belief in the omnipotence of signs" (Baudrillard, 1970/1998, p. 31).

After this broad characterization of consumerism, we may return to the theme of subjectivity. One can summarize their relationship thusly: with the advent of 
consumer society, there has been a fundamental shift in how the subject is produced. We have moved from a modern logic - with its focus on the capitalist mode of production, in which work played a major part - to the postmodern logic, based on a mode of signification through consumption. In sum, under consumerism we have the production and colonization of subjectivity through social signifiers, consumable as commodities: mass production of the subject as consumer and as commodity. Such social signifiers are expressed as images; the corpus of such images and representations corresponds to a social imaginary.

\section{Social imaginary, représentations collectives and collective consciousness}

To offer a broad definition, the social imaginary refers to the world of representation and its relations with both collective and individual imagination: a network of socio-historical images, symbols, and myths through which human beings imagine, organize, and represent meaning. As such, it is a cultural as well as an individual creation, and represents the typical social forms through which we construct reality, articulating and affecting the "subjects' understanding of themselves, their practices, and the places they occupy in society" (Castoriadis, 1975/1987, p. 349).

Historically, the original social imaginaries were symbolic imaginaries: ensembles of typical symbolic forms - rites, rituals, myths, religious systems, and their imagery - that were shared socially. In Analytical Psychology, the symbolic imaginary represents the cultural expression of the symbolic function of the unconscious psyche; its main constituents are représentations collectives (Durkheim, 1912/1995): collective mental categories for acting, thinking, and feeling that are taken for granted. According to LévyBruhl (1910/1985), they are superordinate ideas imbued with intense emotional feeling-values and expectations, usually of a religious or mystical character, that work as general categories of imagination. As symbolic patterns or categories of imagination, they function as a cultural system of projections of unconscious contents, for they are products of our unconscious's structure (Jung, 1921/1971); as such, they have their roots in the archetypes, the collective unconscious in each of us, and are at bottom irrational and emotional - in fact, numinous, fascinating and religious. As a collective mindset, they configure, to a large extent, each individual psyche.

Broadly, the social imaginary also corresponds to the concept of collective consciousness, as the typical collective mentality: "universally recognized ideals or feeling toned collective ideas" (Jung, 1951/1969, para. 54 ), beliefs, and values. Seen as the social imagination - the social ways of imagining, organizing, and representing meaning -, it institutes social categories of identity and otherness, and thus defines both social relations and subjectivity. In sum, it underpins the identity of both society and social actors; as the psychological (imaginary) foundation of social order, it determines how reality is signified, or, indeed, what is real. Therefore, it defines psychological subjectivity.

\section{The Imaginary of Consumption, or ImCon}

The social imaginary of consumer society, as a concept, is here referred to as ImCon. The acronym can be read in two senses: as Imaginary of Consumption, and of Consumerism. In this last sense, the ImCon corresponds to the "-ism", the mass ideology, of a totalizing character, that defines our globalized societies and, indeed, our epoch. It can be defined as a semiotic and ideological social imaginary whose superordinate idea, categorical imperative, and absolute principle are consumption. As such, it encompasses some factors that are central for consumer society, for, as seen, consumption is essentially based on what is imaginary - it is founded upon imagery, imagination and imaginary things, and the irrational.

The sign defines the ImCon's corpus of images and representations: it is a semiotic-semiological system whose fundamental elements are commoditysigns and their corresponding consumption dreams. Here it becomes clearer that this work's theorizing on the ImCon was essentially based on Baudrillard's semiotic analysis of consumer society and hyper reality; some of its central concepts are explained in what follows. First, it is signs, as social signifiers circulated as images, which constitute the ImCon as a regime of signification. To offer a short definition: the sign is the form of representation whose signification is artificial or conventional and based on the split between signifier and signified, which can only have an arbitrary relationship. (In this sense the sign is the opposite of a true symbol).

In much the same way that the commodity was the central element for the analysis of capitalism in Marx, the sign is the crucial element for the system of consumption; its structure and logic are at the "very heart of the commodity-form" (Baudrillard, 1973/1981, p. 146). In other words, the political economy of the sign defines consumerism. However, it is the fusion of commodity and sign, the commoditysign, that constitutes the unit of analysis and elemental, structuring form of consumer capitalism, 
condensing the latter's logics of commodification and colonization and its ideology (Baudrillard, 1973/1981). In turn, commodification can be defined as the production of sign-values (or fetish) connected to the fabrication of commodity-signs, which follows the logic of advertising, consisting in the manipulation of signs (as atoms of social meaning systems), arbitrarily combining and recombining their abstracted, emancipated components (signifier and signified). The sign (as image, or representation) is then attached to a product, or becomes a product itself, thereby signifying particular relations, experiences, or forms of subjectivity, as commodities. This final result corresponds to the concept of "consumption dream", as the fetish (Baudrillard, 1973/1981) or phantasmagoria (Benjamin, 1999; Marx, 1867/1990) of the commodity-form.

Advertising embodies the cultural mechanics for constructing sign-value and commodity-signs (Goldman \& Papson, 1996). As mentioned, such mechanics involve the manipulation of signs aimed at the fabrication of sign-value, which is generally equal to social desire. This process follows the dynamics of fetishization, of producing, educing and instrumentalizing desire and emotion for commodities, which will then produce the subjects of consumption. Fabricating subjectivity, therefore, is central to its logic: advertisements "operate on the premise that signifiers and signifieds that have been removed from context can be rejoined to other similarly abstracted signifiers and signifieds to build new signs of identity. This is the heart of the commodity sign machine" (Goldman \& Papson, 1996, p. 5). In this sense, advertising explains a social logic and serves as its metonym. Such logic, however, is also seen in the marketing, mass media, information, communications, fashion, and entertainment industries: it is the logic of our present-day Culture Industry.

Advertising and marketing, as the factories of commodity narratives (Goldman \& Papson, 1996), represent the prime makers of the ImCon, and as such function as social architects of desire, as society's designers of consumption dreams - in fact, as its dream industry. By fashioning this semiotic imaginary, they also fashion its subjects: the consumers. However, colonizing subjectivity is only part of its totalizing or totalitarian character. The process of semiotic formation involved in the production of marketable commodity-signs demands colonizing progressively the whole of culture and history, manipulating and transforming every component of every system of meaning and expression - narratives, images, representations, symbols - into commodity-signs.
Therefore the discourse of advertising, as a global hegemon, tends to absorb all forms of discourse, expression and signification - eventually arriving at what Baudrillard (1981/1994) called the era of absolute advertising. This logically implies the colonization and commodification of previous symbolic imaginaries, indeed of culture itself, engineering a mutation or colonization of imaginaries (Augé, 1999; Gruzinski, 1988): from the order of symbols, we have moved to the order of signs, and toward the order of simulacra and hyper reality.

\section{The production of subjectivity under the Imaginary of Consumption}

In order to explore how the regime of consumerism and its ImCon institute psychological subjectivity, a different theoretical perspective will be deployed: it is essentially based on the employment of old sociological concepts - représentations collectives and participation mystique - to advance a Jungian psychological understanding of the consumer subject. The main idea is that the fabrication of such subject involves a process of totalization of subjectivity, including the colonization of the unconscious psyche. This process can be seen in two complementing levels. The first level refers to the production of the subject as a consumer; the processes involved in such production are chiefly based on the concepts of desire and identity, and have already been studied by many authors (e.g. Baudrillard, 1970/1998; Bauman, 2007; Featherstone, 2007; Guattari \& Rolnik, 2006). The second level refers to the engineering of the subject as a commodity. Its theoretical discussion is derived from the different, innovative approach mentioned, and intends to describe some of its psychological consequences and dynamics but in a more hypothetical way; it aims at providing ideas for future research.

\section{The production of the subject as a consumer, or the consumer-subject}

This process is based on consumerism's nexus, the fabrication of functional irrationality - which founds the fabrication of its subjects. Such functional irrationality is commandeered through desire, which has been elevated to the motor of social consumption (Ewen, 1988), the motivational structure of consumerism (Belk, Ger, \& Askegaard, 2003). This development is only logical. If mass production required capitalism to produce a mass society of consumers, under total consumerism the functioning and reproduction of the system will depend on the (re)production of desires as a function of unlimited mass production and mass 
consumption: engineering mass desires represents the control over production not merely of consumers, but of their unlimited demand. To attain that kind of control the system of consumption had to tap into the irrational and imaginary sides of existence, to engineer not mere needs or wants - which are finite and limited, of a more rational nature, and related to use-value - but desires - which are unlimited and related to sign-value and sumptuary value, i.e. to irrational, intangible, imaginary things. Thus the objects of desires become unrestricted: anything can be the object of desire. The objective, therefore, will be to create and program desire as an unlimited, objectless all-consuming desire as the central mode of psychic functioning of the subjects of a mass society. As Marcuse (1955/1966) noted, this process is equivalent to a form of social control that does not aim at reason and mind - it aims at managing and dominating the gut feelings, the emotional, the irrational, the very foundations of our psychological being: the instincts, the irrational libido (in Jung's sense). Thus, to colonize and control desire means to determine the directions and forms of psychic energy: it is tantamount to controlling the functioning of the psyche, including our unconscious psyche. In this sense, subjectivation under consumerism necessarily involves the colonization of the unconscious - a theme studied in depth by Deleuze and Guattari (1972/2004), who have written profusely about the "machinic unconscious", the basis for the hegemonic fabrication of subjects as "desiring-machines".

In sum, it is the fetish fabricated as commoditysigns that defines and colonizes desires (and other irrational factors: emotions, imagination, instincts); desires that, in turn, signify and institute the social subject as a consumer. Such desires are directed by one major desire: having an identity. This identity is obtained via the consumption of commodity-signs, endowed with social signification and differentiation, and is based on their magical, imaginary transference to the consumer. Thus such identity, or sense of self, is necessarily exteriorized and mediated by signs. The traditional inner sense of identity and subjectivity - a self which is anchored in inner psychic life, which provides a sense of inner integrity and individuality - is denied and replaced: the locus of self becomes thoroughly other-directed, or extrinsic (Ewen, 1988). Davis (2003) summarizes this point:

We identify our real selves by the choices we make from the images, fashions, and lifestyles available in the market, and these in turn become the vehicles by which we perceive others and they us. In this way ... self-formation is in fact exteriorized, since the locus is not on an inner self but on an outer world of objects and images valorized by commodity culture. (p. 44)
And Judith Williamson (1978) complements it.

We are both the product and the consumer; we consume, buy the product, yet we are the product. Thus our lives become our own creations through buying; an identi-kit of different images of ourselves, created by different products. We become the artist who creates the face, the eyes, the life-style. (p. 70)

Thus, at this level, the consumer's social identity is equivalent to his identification with identikits: as cultural and imaginary roles, models, lifestyles, that are socially recognized in a hierarchy of values, and involve a continuous "personal" combination and recombination of commodity-signs. Therefore, social identity derives essentially from the consumer's patterns or styles of consumption, which personalize and signify him socially.

\section{The production of the subject as a commodity, or the commodity-subject}

The analysis of this form of subject-production is based on seeing the ImCon as a simulacrum of symbolic imaginary, myth (Baudrillard, 1970/1998), or religion, whose central element is not the symbol, but the sign - in fact, the commodity-sign. The central proposition is that the mass (re)production, circulation, and proliferation of commodity-signs and their artificial numen acquire the status of and function as a desacralized religion: the religion of consumerism. Its system of signs - its semiurgies and imagery - functions as the symbolic systems of old: it establishes the categorical principles, the distinctions and ordering, the value and meaning of things, people, and acts. As in primitive societies, such "religion" is totalizing: it affects and determines every facet of life and world; it has its own irrationality and metaphysics, based on a fascination for the commodity.

Under this semiotic religion, the fabrication of subjectivity is based on archaic identity and mimesis between subject and object (the object being a sign). We may summarize it with this formula: what characterizes consumerism and its subject is participation mystique with the commodity. Participation mystique is a concept derived from anthropology (Lévy-Bruhl) and the study of primitive psychology. For Jung (1921/1971), it denotes an archaic identity based on a mystical and emotional connection between subject and object in which both remain non-differentiated or conflated. It corresponds to the primordial unconscious state of the infant and the primitive, prior to the formation of a distinct individuality, in which part of the subject's psyche is projected upon the object (or environment) and 
remains bound to it through a symbol (or symbolic system). Being a symbolic phenomenon, it is relatively indifferent to logical, rational contradiction. The forms, emotional tones and characteristics such identity and projection assume are conditioned by the représentations collectives.

Therefore, subjectivity becomes equal to archaic identity, or irrational identification: an emotional, imaginary, unconscious identity that bonds the subject to an object that is external to his psyche, from which he is indistinct. Within consumer society, said object can be analyzed in two different levels. The subject is instituted in participation mystique with:

1. the commodity-sign (as desire, consumption dream, ideology): this corresponds to the production of the subject as consumer; his identity requires identifying with the identikits, the "dreams" of a social status and ways of being, the unanchored meanings appropriated and offered (as commodities) by the ImCon.

2. the whole ImCon. At this level, there is a nearly complete identification with the totalizing ideology of consumerism - translated as general beliefs, values, rites, models, etc. - which functions as archaic représentations collectives: a totalizing worldview that is simply taken for granted as reality. Within such reality the subject's psyche is molded, or unconsciously conditioned: the semiotic representations operate as social categories - of apperception, imagination, understanding - and aim at totalizing perception, experience and behavior. Instead of being expressed by symbolic imaginaries, the instincts - and thus the unconscious psyche - are directed and signified by signs: the main ritual is to consume the latter. In short, here commoditysigns substitute symbolic archetypal-mythic narratives; their fetish fascinates and entrances, and subjectivity is projected upon them.

As with old religious imaginaries, the main result is a mimesis with the imaginary, with its logic and contents, with its machinic phantasmagoria: mimesis in the sense of homoousia and homology, of reproduction and replication. This means that the fabrication of the subject mirrors the fabrication of commodity-signs, i.e., it follows the logic of commodification: identity or subjectivity becomes a random association of signifieds and signifiers, of images and social meanings - consumed and taken as identity components. Therefore the imperative to be a subject - the hegemonic form of subjectivation - is to become a marketable commodity.
Such subject-form represents the apotheosis of "Homo consumens" (Bauman, 2007, p. 99), a new subject whose identity amounts to near-complete identification with the persona. However, the new ImCon personae are not merely imaginary, but arbitrary, artificial and superficial: they are composites of image-signs of identity industrially produced and socially recognized. Maffesoli (1989) writes that such personae have replaced the notion of modern individual, and describes them: they are fluid, directionless, performative identities. Each consists in an amalgam of roles; as the consumer-subject is supposed to consume and change them according to the logic of the markets, constantly upgrading his self-image, his mutating identity will be defined by "perpetually playing roles ... in a pointless theatre of the world" (Tester, 1993, p. 77). Maffesoli (1988) affirms that, in opposition to individuation, this is a subject characterized by almost complete de-individualization, by "the 'losing' of self into a collective subject" (p. 145) - or, in fact, its dissolution into a social imaginary of signs.

Thus what defines the consumer-subject is the salability of the persona(e) chosen and consumed, salability which is relatively arbitrary and changes all the time in accord with market demands. In fact, more than mere sources of identity and definers of social relations, the commodity-sign and the act of consumption are becoming the only foundations of being. As Benson's quote above claims, mutating Descartes' cogito, "I shop therefore I am": shopping (consuming) thus becomes the basic certainty, guarantee, and guarantor of existence. The commodity-subject, or commodified self, thus becomes the subject of contemporary consumption societies. If this is so, it signs a further anthropological mutation. If the human being under symbolic imaginaries was defined as homo symbolicus (Cassirer, Eliade); and under a semiotic imaginary we have the homo consumens (Bauman), defined by the consumption of signs - here there appears a transition from homo consumens to homo commoditas. If consumer society and the ImCon establish and impose a process of subjectivation that becomes essentially identical to commodification - then they will engender a subject whose identity is defined by being a commodity. The logic and practice of this process of commodification of self (Davis, 2003) appear clearly in the contemporary movement of "personal branding" (Hearn, 2008), which consists in manipulating signs and images of oneself in order to become a brand - a process of selfcommodification, of turning oneself into a commoditysign. "Sell your soul" here is not merely metaphoric: "We must brand, package and market ourselves so that we are desirable. Under what slogan will you be sold?" (Nordström \& Riddestråle, 2000, p. 242). 


\section{Participation mystique and its effects on the consumer-subject}

The state of full participation mystique induced and fabricated by the ImCon implies a number of effects upon the subject it produces - effects that are related to certain psychological dynamics that are typical of participation. The first can be called Narcissism - though in a different sense. Contra psychoanalytic interpretations, the Narcissus myth (Baudrillard, 1970/1998; Lasch, 1984; McLuhan, 1964/1994) in fact expresses the dynamics of participation mystique: projection of subjectivity, or the whole psyche, as self-image, and radical and deadly alienation due to non-recognition of the projection. However, under the imaginary of consumption there is a total reversal: it is not the Narcissus-consumer who projects anything; all self-images are already projected a priori and only available as identikits, with which he has to identify (consume) in order to have any sort of identity. In a radical inversion, what in fact projects "subjectivity" (as semiotic contents) is the imaginary upon the consumer. Thus, as in the myth, the Narcissus-consumer is condemned to Echo the ideological imaginary, compulsorily replicating it, and hence remaining bonded to, fascinated by, and indistinguishable from its dream-world.

Narcissus also means narcosis, narcotic: participation means remaining in a dreamy, lethargic state, the primordial unconscious state (Jung, 1921/1971). That is, identity with the imaginary keeps the subject functioning in a dreamy, unconscious state, which is typical of primitives and children. This idea corresponds to what Walter Benjamin (1999) called Traumschlaf, a "dream-filled sleep", the collective dream characteristic of consumer society. Other authors have also connected such somnambular dream state with consumerism. For instance, Marcel Gauchet (2009) says we are living under an anesthésie collective.

Other logical effects of forceful participation include dependency and inferiority. Indeed, if the psyche is "outside", if subjectivity is by definition exteriorized, that will engender an unconscious sense of emptiness and inferiority, a sort of "lack" of psyche, of individuality, which the primitives call "loss of soul"; and an unconscious bond (dependency) to the signs that socially signify subjectivity, i.e., to the whole ImCon. Both effects are connected to a central characteristic of unconscious identity: alienation from subjectivity and individuality. In effect, as subjects are produced as commodities, massification and annihilation of individuality become prevalent. That is connected to a characteristic psychological functioning that the ImCon, as a mass ideology, induces and produces in its subjects: a typical crowd psychology, or mass mentality. Indeed, if consumerism functions based on the manipulation of irrational, unconscious forces, the control of pre-logical thought, and the fostering and commercialization of mass feelings, emotions, and dreams - then the unconscious functioning that it engenders can only be seen as that of the horde: unstable, irrational, suggestible, easily carried away. Moreover, as any commodity, the massified subject cannot help but feel disposable. That is mirrored in the acceleration of rate at which consumers assume and shed identities - for the semiotic identities are disposable by definition, and need to be discarded fast so as to assume/consume new ones.

\section{The homo commoditas}

Logically, then, the commodity-subject will mirror the characteristics of the commodity: transient, disposable, superficial, and artificial. But more than that: inasmuch as the subject is formed in identity with the imaginary and becomes identical with its consumption dreams, s/he will resemble an assemblage of unchained signs, disconnected from reality, exchangeable against other signs or commodities. Subjectivity thus becomes a "pure and random play of signifiers" (Jameson, 1991, p. 96), a bricolage or pastiche of signs. Theoretically, this idea reveals how a cultural mutation (total capitalism-consumerism) is connected to a mutation of imaginaries (from symbolic to semiotic to simulacrum); both mutations shape a corresponding anthropological mutation: the subject as a commoditysign, turning into a simulacrum.

A parallel process: as culture is dissolved and volatilized into signs to be consumed - and the signs are emancipated from any reality - so is its subject. Baudrillard (1973/1981) mentioned this phenomenon of consumerism in an important passage that summarizes the argument of "total colonization" by the ImCon of both social reality and subject: "Homology, simultaneity of the ideological operation [of commodification] on the level of psychic structure and social structure" (p. 100). Here we have homology between commodity-logic and subjectivation: the subject becomes a (commodity-)sign and, as referents disappear (signs become unchained simulacra), the subject turns progressively into a simulacrum. After the advent of homo commoditas, the consumercommodity, and in line with the process of mimesis with consumer society and its imaginary, this daunting 
prospective signs a total anthropological mutation: the epiphany of the homo simulacrum.

Under such homology, the prospect is for the subject to be produced, reproduced, exchanged and circulated as a hyper real sign, or, put differently, a surface, a one-dimensional persona that is not even a mask, but a mere screen for the projections of commodity-imagery - a "pure screen, a pure absorption and re-absorption surface of the influent networks" (Baudrillard, 1988, p. 27), a volatile refraction of the ImCon. Augé (1999) described it as:

The fictional self, the peak of a fascination which is begun in any relationship exclusive to the image, is a self without relationship and as a result without any basis for identity, liable to be absorbed by the world of images in which it believes it can rediscover and recognize itself. (pp. 116-117)

The fictional self is not a self that is merely decentered, distributed, flexible, fragmented, saturated - the postmodern self. As the sign is empty, the end product of participation mystique with it is an empty self (Cushman, 1990). Such idea is behind some subjective phenomena that have been much discussed in our consumption societies. The empty self is a self whose unconscious feeling of emptiness is accompanied by everlasting restlessness and insecurity or fear, which are constantly fed by the ImCon. The main effect of such feelings appears as a Pantagruelic desire for consumption: an extreme longing for sensations, instant stimuli, constant overexcitement and pleasure - a craving for full immersion in the dream-world of commodities and images that provides fast meaning and sense, instantaneous filling of the emptiness by signs and their technicolor phantasmagoria, consumerism's oneiric opiate or soma. Without which - without the participation mystique - life seems empty, for the self feels empty: meaninglessness and feelings of dreary aridness and vapidity might ensue; or else an utter incapacity for feeling anything or desiring anything, a pervasive numbness - in sum, a ghostly sense of inner, corroding vacuum: non-existence. This condition (which can, of course, assume many other forms) corresponds to what Bernard Stiegler (2006) described as disindividuation, resulting from "the addictive system of consumption" and its "symbolic misery":

At this stage, consumption releases more and more compulsive automatisms, and the consumer becomes dependent on the consumption hit. He suffers, then, from a deindividuation syndrome that he only manages to compensate for by intensifying his consumer behavior, which at the same time becomes pathological.
The consumer, in this sense, turns into a sort of addict - for the goal of consumerism is to industrialize desire as analogous to a craving for potent drugs and their vanishing effects; to engineer a psychic "objectless craving" (Baudrillard, 1970/1998, p. 78), a boundless voracity for meaning. Without the consumption hit, both reality and self seems empty, hollow. Consumption and its imaginary then offer strong doses of unreality: their best-selling promises are the transcendent beliefs that there is no reality, and that the consumer can be anything - every subjectivation is possible: by manipulating signs of identity, consumers can become any of their possible selves, and be whatever they want - the way one changes clothes. Thereby "consumer society offers the individual the opportunity for total fulfillment and liberation" (Baudrillard, 1968/1996, p. 260). Mirroring the emptiness of the commodity-sign, which allows it to carry any sign-value, the consumersubject flies rootless through the seemingly infinite possibilities of being promised by the commodity. No roots, no substance, no limits: an omnipotent yet empty commodity-subject with a belief (nay delusion) that she is original, unique, free, electing sovereignly her lifestyle and personality.

To conclude this article, let me summarize it by recalling the epigraph by Lefebvre: We are surrounded by emptiness but it is an emptiness filled with signs. Indeed; and by consuming and identifying with the ImCon, we become that emptiness filled with signs. Or, as T. S. Eliot wrote just before the great catastrophe: We are the hollow men, we are the stuffed men. Total consumerism needs and seeks to engineer hollow women and men, atomized, stuffed and stupefied with dreams of consumption, absolutely identified with empty desires. One could say that we are now such stuff as consumption dreams are made on; and our little life is rounded with a narcotic sleep. For the mass of consumercommodities, the subjects mass-produced by consumer society, life then becomes a succession of commoditydreams, consumed and rapidly discarded in a perpetual dream-world. To paraphrase Calderón de la Barca's famous play: under the regime of consumerism, $L a$ vida es un sueño de consumo; y los sueños y los sujetos, mercancias son ("Life is but a consumption dream; and dreams and subjects are only commodities").

\section{References}

Augé, M. (1999). The war of dreams: exercises in ethno-fiction. London: Pluto Press.

Baptista, L. A. S. (2013). The cities of need: capitalism and subjectivity in the contemporary metropolis. Psicologia \& Sociedade, 25(n.spe.), 54-61.

Bauman, Z. (1997). Postmodernity and its discontents. Cambridge: Polity Press. 
Bauman, Z. (2007). Consuming life. Cambridge: Polity Press.

Baudrillard, J. (1981). For a critique of the political economy of the sign (C. Levin, Trans.). St. Louis, MO: Telos Press. (Original published 1973)

Baudrillard, J. (1988). The ecstasy of communication. Cambridge, MA: MIT Press.

Baudrillard, J. (1994). Simulacra and simulation (S. F. Glaser, Trans.). Ann Arbor, MI: University of Michigan Press. (Original work published 1981)

Baudrillard, J. (1996). The system of objects (J. Benedict, Trans.). London: Verso. (Original work published 1968)

Baudrillard, J. (1998). The consumer society: Myths and structures. London: Sage. (Original work published 1970)

Belk, R., Ger, G., \& Askegaard, S. (1996). Metaphors of consumer desire. Advances in Consumer Research, 23, 368373.

Bell, D. (1976). The cultural contradictions of capitalism. New York: Basic Books.

Benjamin, W. (1999). The Arcades Project (H. Eiland \& K. McLaughlin, Trans.). Cambridge: The Belknap Press of Harvard University Press.

Benson, A. L. (Ed.). (2000). I shop therefore I am: Compulsive buying and the search for self. New Jersey: Jason Aronson.

Castoriadis, C. (1987). The imaginary institution of society (K. Blamey, Trans.). Cambridge: MIT Press. (Original work published 1975)

Castoriadis, C. (1997). The "rationality" of capitalism. In C. Castoriadis, Figures of the unthinkable (pp. 81-122). Retrieved from http://www.notbored.org/FTPK.pdf

Cushman, P. (1990). Why the self is empty: Toward a historically situated psychology. American Psychologist, 45(5), 599-611.

Davis, J. E. (2003). The commodification of self. Hedgehog Review, 5(2), 41-49.

Deleuze, G. \& Guattari, F. (2004). Anti-Oedipus (R. Hurley, M. Seem, \& H. R. Lane, Trans.). London: Continuum. (Original work published 1972)

Dufour, D.-R. (2008). The art of shrinking heads: The new servitude of the liberated in the era of Total Capitalism. Cambridge and Oxford: Polity.

Durkheim, É. (1995). The elementary forms of religious life (K. E. Fields, Trans.). New York: Simon \& Schuster. (Original work published 1912)

Ewen, S. (1988). All consuming images. New York: Basic Books.

Featherstone, M. (2007). Consumer culture and postmodernism ( $2^{\mathrm{a}}$ ed.). London: Sage.

Gauchet, M. (2009). Marcel Gauchet: "nous sommes sous le coup d'une anesthésie". Retrieved from http://www. latribune.fr/actualites/economie/france/20090724trib 000403499/marcel-gauchet-nous-sommes-sous-lecoup-d-une-anesthesie-.html

Giroux, H. A. \& Pollock, G. (2011). How Disney magic and the corporate media shape youth identity in the digital age. Retrieved from http://www.truth-out.org/opinion/ item/2808:how-disney-magic-and-the-corporatemedia-shape-youth-identity-in-the-digital-age

Goldman, R. \& Papson, S. (1996). Sign wars: the cluttered landscape of advertising. New York: The Guilford Press.

Gruzinski, S. (1988). La colonization de l'imaginaire. Paris: Gallimard.

Guattari, F. \& Rolnik, S. (2006). Micropolitica: cartografias del deseo. Madrid: Traficantes de Sueños.
Hearn, A. (2008). 'Meat, Mask, Burden': Probing the contours of the branded 'self'. Journal of Consumer Culture, 8(2): 197-217.

Jameson, F. (1991). Postmodernism, or the cultural logic of late capitalism. Durham, NC: Duke University Press.

Jung, C. G. (1969). Aion: Researches into the phenomenology of the self (R. F. C. Hull, Trans). In Collected Works Of C. G. Jung, Vol. 9ii. Princeton, NJ: Princeton University Press. (Original work published 1951)

Jung, C. G. (1971). Psychological types (H. G. Baynes, Trans). In Collected Works Of C. G. Jung, Vol. 6. Princeton, NJ: Princeton University Press. (Original work published 1921)

Lasch, C. (1984). The minimal self: Psychic survival in troubled times. New York: W.W. Norton.

Lefebvre, H. (1971). Everyday life in the modern world. New York: Harper \& Row.

Lévy-Bruhl, L. (1985). How natives think (L. Clare, Trans.). Princeton, NJ: Princeton University Press. (Original work published 1910)

Leys, C. (2007). Total capitalism: Market politics, market state. London: Merlin Press.

Liodakis, G. (2010). Totalitarian capitalism and beyond. Surrey,UK: Ashgate.

Lukács, G. (1971). History and class consciousness (R. Livingstone, Trans.). London: Merlin Press. (Original work published 1923)

Maffesoli, M. (Ed.). (1988). The sociology of everyday life. London: Sage.

Maffesoli, M. (1989). Jeux de masques: Postmodern tribalism. Design Issues, IV(1), 141-151.

Marcuse, H. (1966). Eros and Civilization. Boston: Beacon. (Original work published 1955)

Marx, K. (1978). Grundrisse. In R. C. Tucker (Ed.), The MarxEngels reader (2 ${ }^{\mathrm{a}}$ ed., pp. 222-293). New York: WW Norton. (Original work published 1858)

Marx, K. (1990). Capital: Critique of political economy (Vol. 1, B. Fowkes, Trans.). Harmondsworth: Penguin. (Original work published 1867)

McLuhan, M. (1994). Understanding media: The extensions of man. Cambridge, MA: MIT Press. (Original work published 1964)

Nordström, J. \& Riddestråle, K. (2000). Funky business: Talent makes capital dance. Harlow, UK: Pearson.

Stiegler, B. (2006). The disaffected individual in the process of psychic and collective disindividuation. Retrieved from http://arsindustrialis.org/disaffected-individual-processpsychic-and-collective-disindividuation

Tester, K. (1993). The life and times of post-modernity. London: Routledge.

Williamson, J. (1978). Decoding advertisements. London: Boyars.

Submissão em: 12/03/2015

Revisão em: 24/10/2015

Aceite em: 06/11/2015

Marlon Xavier é doutor em Psicologia Social pela Universidad Autónoma de Barcelona e professor doutor adjunto da Universidade de Caxias do Sul/RS, Brasil. Endereço para correspondência: Rua Sofia Veloso, 15, apto. 504. Porto Alegre/RS, Brasil. CEP 90150-140 E-mail: marlonx73@gmail.com 